Original Research Paper

\title{
Analysis of Validation of Instruments to Measure Student's Critical Thinking Ability and Science Literation
}

\author{
Tomi Widiatmo $^{1 *}$, A. Wahab Jufri ${ }^{1,2}$, Jamaluddin ${ }^{1,2}$ \\ ${ }^{1}$ Master Program of Science Education, University of Mataram \\ ${ }^{2}$ Biology Education Study Program, University of Mataram
}

Article history

Received: May $20^{\text {th }} 2019$

Revised: July $11^{\text {th }} 2019$

Accepted: July $14^{\text {th }} 2019$

*Tomi Widiatmo: Master

Program of Science Education,

University of Mataram,

Indonesia;

Email:

tomiwidiatmo@gmail.com

\begin{abstract}
Abstrak: This study aims to produce a valid and reliable instrument to measure the influence of guided inquiry learning models on students' critical thinking skills and scientific literacy through assignment techniques. The instruments of this study are a syllabus, learning implementation plan (RPP), questions of critical thinking and scientific literacy. An analysis of validity is carried out by proving the content and criteria validity. The results of the analysis of validity, reliability, level of difficulty, and differentiation indicate that the instrument has met the criteria that are feasible and valid for measuring students' critical thinking and literacy skills.
\end{abstract}

Keywords: Validity; Research Instruments; Critical Thinking; Science Literacy; Guided Inquiry

\section{Introduction}

Critical thinking skills are one of the fundamental abilities that must be developed in students. The increasingly rapid development of science demands a generation that is critical in facing complex problems. This background indicates that critical thinking skills should be trained early, especially for students at the junior secondary level (Udi \& Cheng, 2015). Critical thinking is not just an ability to solve problems related to learning in school but also shapes the development of students' habits of mind for each problem they face.

Ennis (1985) defines the ability to think critically as a thinking ability that emphasizes reasonable reflective thinking in constructing a conclusion or decision making. The technical link between cognitive and behavioral aspects with the aim that students are not only able to solve problems but also develop their mindset and make it something behavioral (Udi \& Cheng, 2015). The critical thinking taxonomy developed by Ennis includes; (1) elementary clarification; (2) basic support; (3) inference; (4) advanced clarification; and (5) strategic and tactics (Ennis, 1985).

Besides the ability to think critically, one of the target competencies of students in the 21st Century skills is being developed is scientific literacy. Students are required to be able to build inference through a process of critical and creative thinking with data/information based on broad insights. Extensive science insight is an indication of the achievement of scientific literacy. Science literacy is defined as the ability to read events or natural phenomena and draw conclusions using the scientific method (Setiadi, 2013).

PISA defines scientific literacy as a skill or capacity to use scientific knowledge through scientific processes, namely identifying problems, drawing conclusions based on evidence to understand things and make decisions in the form of concrete actions (Firman, 2007).

The definition of scientific literacy above shows that there is a close link between literacy and critical thinking. Literacy science refers to the ability to search and manage knowledge through various sources through scientific and critical thinking processes. Aspects that can be used as indicators of the achievement of scientific literacy are: (1) explain scientifically phenomena; (2) evaluate and design scientific inquiry; (3) interpreting data and evidence scientifically (OECD, 2016).

The ability to think critically and scientific literacy as an indicator of the achievement of cognitive higher-order skills (HOCS) which one of the main goals in the field of education, especially in science and mathematics (Zohar \& Dori, 2003). One of the measurement instruments of HOCS in Indonesia is usually in the form of multiple choice questions, for example in the National Examination 
question known as HOT Question (Higher-Order Thinking). Puspendik (2018) has reviewed the achievement of education in Indonesia based on the results of the National Examination compared with IIUN (National Examination Integrity), and its conformity with PISA 2015 results in mastery of science, mathematics, and literacy. The study of these achievements resulted in a policy of changing the national grid that emphasized reasoning ability which became the basic of critical thinking skills.

The National Examination Data (UN 2018/2019) from the Center for Educational Assessment (Puspendik) indicates that the students have low problem-solving ability of HOT questions ability, especially in NTB (Figure 1). The low achievement indicates that students' critical thinking skills and scientific literacy are still low.

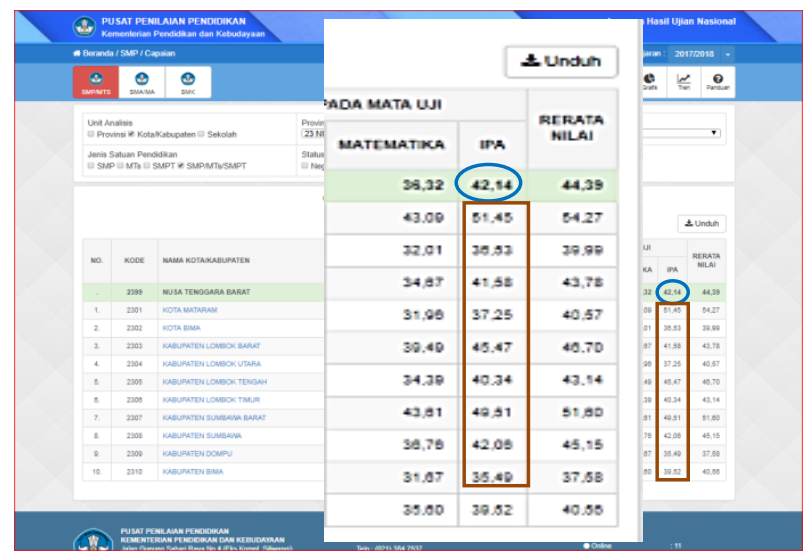

Figure 1: Achievement of the NTB Province National Examination Value in 2018

The results of the latest survey from PISA published by the Ministry of Education and Culture of the Republic of Indonesia, the score of Indonesian scientific literacy is 403 (OECD, 2016). This number experienced a significant increase from 2012, which amounted to 382. This placed Indonesia ranked 66 out of 72 participating countries. This figure is still far from the average science score of all participants, namely 501. The score shows that the quality of learning science, especially scientific literacy and critical thinking skills of junior high school students in Indonesia is still far below the OECD countries.

Teacher creativity in designing learning that can develop critical thinking skills and scientific literacy is one of the goals of education in this century. Natural Science (IPA) is a subject that has special characteristics, namely the involvement of students in observation. The object of science learning is objects and natural events around it which provide space for students to study it in the inquiry. One learning model that emphasizes inquiry activities is the Guided Inquiry learning model.

The Inquiry is a learning model that emphasizes the process of scientific thinking in solving problems that are using the ability to think critically, logically, and creatively with the guidance of teachers (Llewellyn, 2015). Wallace and Metz suggest that the most important thing in applying guided inquiry is the activity of students as researchers with teacher guidance, who train students to be able to act as problem solvers (Bilgin, 2009). Hanson (2012) suggests the syntax of guided inquiry learning in several phases, namely: (1) Orientation; (2) Exploration; (3) Concept Formation; (4) Application; and (5) Closure. Through the implementation of a guided inquiry model, it is expected that students' critical thinking skills and scientific literacy can increase.

This study aims to determine the effect of Guided Inquiry learning models on critical thinking skills and scientific literacy through assignment techniques. In measuring the critical thinking skills and scientific literacy and the implementation of inquiry learning models, guidance is needed research instruments that can measure precisely so that it can collect accurate data and can test the hypotheses that have been proposed (Wiersma, 1986). The requirement for an instrument is said to be feasible as a measuring instrument based on empirical facts and theoretical reasons for producing inference is called validity (Retnawati, 2016).

The focus of the study in this paper is to design a research instrument that will be used to measure students' increased critical thinking skills and scientific literacy in science subjects in the material Interaction between Living Beings and their Environment by using a Guided Inquiry learning model. The instrument will be proven and analyzed its validity so that it is feasible to be used as a valid measuring instrument.

\section{Method}

The instruments analyzed were a syllabus, learning implementation plan (RPP), student worksheets (LKPD), and test instruments in the form of questions of critical thinking and scientific literacy. This instrument will be used in the quasiexperimental study with the design of the pretestposttest nonequivalent control group design that will be carried out with a completely randomized design (Sugiyono, 2018). 
Table 1: Research Design

\begin{tabular}{lll}
\hline \multirow{3}{*}{ Learning model } & \multicolumn{2}{l}{ Technique Assignment } \\
\cline { 2 - 3 } & $\begin{array}{l}\text { Individual } \\
\text { assignments }\end{array}$ & $\begin{array}{l}\text { Group } \\
\text { Assignment } \\
\left(\mathrm{Y}_{1}\right)\end{array}$ \\
\hline Guided Inquiry $\left(\mathbf{X}_{1}\right)$ & $\mathrm{X}_{1} \mathrm{Y}_{1}$ & $\mathrm{X}_{1} \mathrm{Y}_{2}$ \\
Conventional $\left(\mathbf{X}_{2}\right)$ & $\mathrm{X}_{2} \mathrm{Y}_{1}$ & $\mathrm{X}_{2} \mathrm{Y}_{2}$ \\
\hline
\end{tabular}

Retnawati (2016) suggests that the steps to developing a good test instrument are: (1) determining the purpose of compiling the instrument; (2) looking for relevant theories or material coverage; (3) compile indicators of instrument items / questions; (4) compiling items of instruments; (5) content validation; (6) revisions based on validator input; (7) conduct tests on the corresponding respondents to obtain participant response data; (8) conduct analysis (reliability, level of difficulty, and differentiation); and (9) assembling instruments. The purpose of the preparation of the instrument was adjusted to the research objective, namely to develop instruments to measure students' critical thinking skills and scientific literacy after being given the treatment of a guided inquiry learning model. The preparation of syllabus instruments is limited to the scope of class VII material of Semester II Interaction of Living Beings and their Environment. Each instrument is developed based on variable indicators measured by relevant theories.

RPP and LKPD are compiled based on the syntax of the Guided Inquiry model (Hanson, 2012). Instruments for measuring critical thinking skills in the form of a test instrument amount to 10 items with a question grid arranged based on Ennis's critical thinking taxonomy aspects (Ennis, 1985). Scientific literacy measurement instruments in the form of test instruments amounted to 26 multiple choice questions with questionnaires compiled based on 3 aspects of PISA scientific literacy (OECD, 2016)

Content validation is done by considering the judgment of three experts. Validation of the contents will be quantified based on the results of the expert assessment on the validation assessment sheet. The expert agreement index (validator) is obtained from the criteria of the average tabulation value of all data obtained from the validators for each aspect of the study (Table 2). The average value is calculated by the formula:

$$
\bar{x}=\frac{\sum x}{n}
$$

With:

$$
\begin{array}{ll}
\bar{x} & =\text { average score } \\
\sum x & =\text { total score } \\
n & =\text { number of expert validation }
\end{array}
$$

Table 2: Criteria for Assessing the Feasibility of Devices and Assessment Instruments

\begin{tabular}{lll}
\hline Score & Interval score & Criteria \\
\hline A & $>4,20$ & Very good \\
B & $3,41-4,20$ & good \\
C & $2,61-3,40$ & enough \\
D & $1,81-2,60$ & less \\
E & $<1,80$ & Very less \\
\hline
\end{tabular}

(Anwar, 2015)

In addition to quantification, expert validation contains inputs to the research instrument. The instrument was then revised based on input from experts and consulted again after the revision.

After expert validation, the test instrument was tested on the respondent. Respondents in this trial were eighth-grade students of the Mataram IT Junior High School. Respondents were chosen based on the consideration that the material being tested had been studied before. The respondent's data from the trial results are then analyzed for reliability, difficulty level, power of differentiation.

Sugiyono (2018) states that research data is said to be reliable if there are similarities in data at different times. Reliability can be defined as the consistency of a research instrument data in measuring a variable. The level of difficulty is how difficult an item is answered by the test participant or respondent (Susetyo, 2015). The distinguishing factor is the ability of a test question to distinguish between groups of students who are high and low ability (Martondang, 2009).

Instrument reliability was determined using the Cronbach's Alpha or alpha method in the Statistical Product and Service Solution (SPSS) Version 23. The significance test was carried out at the 5\% significance level, meaning the instrument could be said to be reliable if alpha> $r$ was critical of the product moment.

The index of difficulty of an instrument in a matter of description (critical thinking) can be determined using the formula:

$$
p_{i}=\frac{\sum X_{i}}{m \times N}
$$

while for multiple choice questions (scientific literacy) use a formula:

$$
p_{i}=\frac{\sum X_{i}}{N}
$$

with:

$p_{i} \quad=$ proportion answers to certain items (level of difficulty)

$\sum X_{i}=$ the number of test participants who answered correctly 


$$
\begin{array}{ll}
N & =\text { Number of participants who answered } \\
\mathrm{m} & =\text { maximum score }
\end{array}
$$

(Retnawati, H., 2016)

Allen and Yen (1979) state that in general the item difficulty index should be located at intervals of 0.3-0.7.

The differentiator can be determined by the biserial point correlation index through the formula:

$$
r_{p b i s}=\left[\frac{\overline{X_{1}}-\bar{X}}{s_{x}}\right] \sqrt{\frac{p_{1}}{1-p_{1}}}
$$

with:

$r_{p b i s}=$ a biserial point correlation coefficient

$\overline{X_{1}}=$ an average score of $\mathrm{X}$ for test takers who answered

$\bar{X}=$ an average score of $\mathrm{X}$

$s_{x}=$ the standard deviation of score $\mathrm{X}$

$p_{1}=$ the proportion of test takers who answered correctly the item (level of difficulty)

In a question, a different power index is said to be good if it is greater or equal to 0.3 (Retnawati, H., 2016). Through consideration of the criteria of reliability, level of difficulty, and the power of reasoning, the test instrument can be revised properly so that it can be used as a means of collecting accurate research data.

\section{Result and Discussion}

The world of education at this time emphasizes students to master several competencies known as the 21st Century Skills Competencies. Some of them are critical thinking and scientific literacy. Field facts in the form of UN data and PISA 2015 show that achievement figures are still low from the average. Therefore, one of the urgency of the teacher is to continue to develop learning in the classroom that can improve students' critical thinking skills and scientific literacy.
The application of a guided learning model in class VII science learning material for the interaction of living things and their environment is expected to be able to trigger the activity of students in developing their critical thinking skills and scientific literacy. The characteristics of science are the subject matter with the object of study in the form of objects or natural events that students can find in the surrounding environment. Guided inquiry is one of the learning models whose syntax is in line with the characteristics of science learning because it emphasizes the direct interaction of students with science objects through observation.

Learning, of course, requires careful planning as outlined in the learning device. Learning tools are then expected to be valid and can support success and accurately measure critical thinking and literacy skills. Therefore, the learning tool must be carried out validation analysis especially in, educational research. Validation analysis was carried out on the syllabus, lesson plan, LKPD, critical thinking test questions, and science literacy test questions.

The results of content validation conducted by experts showed good results for guided inquiry learning devices and instruments for measuring critical thinking skills and scientific literacy. The experts are lecturers in the University of Mataram's Natural Sciences education master's program which numbered three people. The subjects assessed were assessments of content, language, and time. The expert agreement index (validator) obtained from the criteria for the average tabulation value of all data from the validators for each assessment aspect is presented in the Recapitulation Table of the Results of Expert Validation (Table 3). The suggestions for improvement in each instrument are presented in a table of suggestions for improving the results of expert validation as a basis for revision (Table 4).

Table 3: Recapitulation of Results of Expert Validation on Guided Learning Tools and Instruments of Tests for Critical Thinking and Science Literacy

\begin{tabular}{llllllll}
\hline \multirow{2}{*}{ No } & \multirow{2}{*}{ Learning Media } & \multicolumn{3}{c}{ Expert Validation } & \multirow{2}{*}{ Total Score } & \multirow{2}{*}{ Average } & \multirow{2}{*}{ Critetia } \\
\cline { 3 - 5 } & & I & II & III & & & \\
\hline 1 & Syllabus & 4,3 & 4,3 & 4,1 & 12,7 & 4,23 & Very good \\
2 & Learning Implementation Plan (RPP) & 4,2 & 4,2 & 4,4 & 12,8 & 4,26 & Very good \\
3 & Science Literacy Instrument & 4,25 & 4,33 & 4,0 & 12,58 & 4,19 & Well \\
4 & An instrument for Critical Thinking Skills & 4,25 & 4,25 & 4,16 & 12,66 & 4,22 & Very good \\
5 & Student Worksheet (LKPD) & 4,2 & 4,3 & 4,2 & 12,7 & 4,23 & Very good \\
\hline
\end{tabular}


Table 4: Recapitulation of Instrument Repair Suggestions

\begin{tabular}{|c|c|c|c|c|}
\hline \multirow{2}{*}{ No } & \multirow{2}{*}{$\begin{array}{l}\text { Learning } \\
\text { Media }\end{array}$} & \multicolumn{3}{|c|}{ Validator } \\
\hline & & I & II & III \\
\hline 1 & Syllabus & $\begin{array}{l}\text { - It should be noted again that } \\
\text { some operational verbs on } \\
\text { the basic competency } \\
\text { indicators are aspects of } \\
\text { knowledge (example: KD } \\
\text { 3.7) }\end{array}$ & $\begin{array}{l}\text { - Clarify the KD keeper again } \\
\text { as an Indicator }\end{array}$ & $\begin{array}{l}\text { - Improve the procedure } \\
\text { for decapitation in the } \\
\text { table }\end{array}$ \\
\hline 2 & $\begin{array}{l}\text { Learning } \\
\text { Implementatio } \\
\text { n Plan (RPP) }\end{array}$ & $\begin{array}{l}\text { The formulation of learning } \\
\text { objectives needs to be } \\
\text { supplemented with skills } \\
\text { competencies and attitude } \\
\text { competencies }\end{array}$ & $\begin{array}{l}\text { - Improve Indicator KD4 with } \\
\text { the appropriate operational } \\
\text { verbs }\end{array}$ & $\begin{array}{l}\text { - Clarify teacher } \\
\text { activities in facilitating } \\
\text { student activities }\end{array}$ \\
\hline 3 & $\begin{array}{l}\text { Science } \\
\text { Literacy } \\
\text { Instrument } \\
\end{array}$ & $\begin{array}{l}\text { - Some images need to be } \\
\text { clarified/enlarged }\end{array}$ & $\begin{array}{l}\text { - Clearly matches the scientific } \\
\text { literacy indicators with the } \\
\text { questions in the question grid }\end{array}$ & $\begin{array}{l}\text { - Try distributed } \\
\text { questions according to } \\
\text { Bloom's taxonomy }\end{array}$ \\
\hline 4 & $\begin{array}{l}\text { An instrument } \\
\text { for Critical } \\
\text { Thinking } \\
\text { Skills }\end{array}$ & $\begin{array}{l}\text { - The sentence structure of } \\
\text { the items can still be made } \\
\text { more effective }\end{array}$ & $\begin{array}{l}\text { - Images and graphics are } \\
\text { clarified again to fit the } \\
\text { indicators of critical thinking }\end{array}$ & $\begin{array}{l}\text { - Adjust the time } \\
\text { allocation with the } \\
\text { difficulty level of the } \\
\text { question }\end{array}$ \\
\hline 5 & $\begin{array}{l}\text { Student } \\
\text { Worksheet } \\
\text { (LKPD) }\end{array}$ & $\begin{array}{l}\text { - Images need to be } \\
\text { clarified/enlarged }\end{array}$ & $\begin{array}{l}\text { - Instructions for the control } \\
\text { group must be clearer }\end{array}$ & - Already well \\
\hline
\end{tabular}

Recapitulation of Results of Expert Validation of Learning Tools Guided Inquiry and Instruments of Critical Thinking Tests and Science Literacy shows the average number above 4.0 with good and very good criteria. Based on the results of the content validation, the research instrument can be declared feasible to use with several revisions based on suggestions for improvements that will be consulted again so as to minimize existing errors.

Other considerations besides the validity of the measurement instruments of critical thinking and scientific literacy are reliability, level of difficulty, and differentiation. Analysis of data from the test results of test instruments is presented in table 5. The results of the scientific literacy data analysis showed that there were 6 items eliminated because they were in the invalid category. As for 20 valid items, they met the minimum requirements of reliability, difficulty, and differentiation.

Table 5: Analysis of the Test Results of the Literacy Test Instrument

\begin{tabular}{lccl}
\hline & \multicolumn{2}{c}{ Test of Instrument Feasibility Requirements } \\
\cline { 2 - 4 } $\begin{array}{c}\text { Item } \\
\text { Quest } \\
\text { ion - }\end{array}$ & $\begin{array}{c}\text { Validity of } \\
\text { Criteria } \\
\text { (Pearson } \\
\text { Correlation) }\end{array}$ & $\begin{array}{c}\text { The Difficulty } \\
\text { Level }\end{array}$ & $\begin{array}{l}\text { Difficulty } \\
\text { Questions }\end{array}$ \\
\hline 1 & 0,215 (Invalid) & 0,625 & \\
2 & 0,360 (Invalid) & 0,813 (High) & 0,375 \\
3 & 0,275 (Invalid) & 0,844 (High) & 0,063 \\
& 0,358 & 0,375 & 0,3 \\
4 & 0,493 & 0,906 (High) & 0,313 \\
5 & 0,380 & 0,500 & 0,5
\end{tabular}

\begin{tabular}{|c|c|c|c|}
\hline \multirow[b]{2}{*}{$\begin{array}{l}\text { Item } \\
\text { Quest } \\
\text { ion - }\end{array}$} & \multicolumn{3}{|c|}{ Test of Instrument Feasibility Requirements } \\
\hline & $\begin{array}{l}\text { Validity of } \\
\text { Criteria } \\
\text { (Pearson } \\
\text { Correlation) }\end{array}$ & $\begin{array}{c}\text { The Difficulty } \\
\text { Level }\end{array}$ & $\begin{array}{l}\text { Difficulty } \\
\text { Questions }\end{array}$ \\
\hline 7 & 0,462 & 0,219 & 0,313 \\
\hline 8 & 0,513 & 0,688 & 0,375 \\
\hline 9 & 0,354 & 0,500 & 0,3 \\
\hline 10 & 0,434 & 0,344 & 0,438 \\
\hline 11 & 0,221 (Invalid) & 0,844 (High) & $\begin{array}{l}0,063 \\
(\mathrm{Bad})\end{array}$ \\
\hline 12 & 0,306 (Invalid) & 0,813 (High) & $\begin{array}{l}0,125 \\
(\mathrm{Bad})\end{array}$ \\
\hline 13 & 0,428 & 0,750 & 0,375 \\
\hline 14 & 0,407 & 0,563 & 0,375 \\
\hline 15 & 0,425 & 0,438 & 0,5 \\
\hline 16 & 0,361 & 0,281 & 0,313 \\
\hline 17 & 0,414 & 0,625 & 0,25 \\
\hline 18 & 0,611 & 0,375 & 0,5 \\
\hline 19 & 0,325 (Invalid) & 0,406 & 0,313 \\
\hline 20 & 0,389 & 0,813 (High) & 0,3 \\
\hline 21 & 0,611 & 0,656 & 0,438 \\
\hline 22 & 0,418 & 0,531 & 0,313 \\
\hline 23 & 0,383 & 0,594 & 0,563 \\
\hline 24 & 0,471 & 0,719 (High) & 0,313 \\
\hline 25 & 0,619 & 0,438 & 0,5 \\
\hline 26 & 0,502 & 0,438 & 0,25 \\
\hline $\begin{array}{l}\text { Reliab } \\
\text { Items }\end{array}$ & $\begin{array}{l}\text { ity (Cronbach's } \\
26\end{array}$ & Ipha) $\mathrm{N}$ of & $\begin{array}{l}0,802 \\
\text { (Reliabel) }\end{array}$ \\
\hline
\end{tabular}

The analysis of the data from the results of the testing of critical thinking test instruments is presented in table 5. The results of the analysis of critical thinking test data showed that there were 2 
items eliminated because they were in the invalid category. The 8 valid items have met the minimum requirements both from the reliability and the level of difficulty of the questions.

Table 6: Analysis of the results of the trial Critical Thinking Essay Test Instrument

\begin{tabular}{lll}
\hline \multirow{2}{*}{$\begin{array}{l}\text { Question } \\
\text { item }\end{array}$} & $\begin{array}{l}\text { Test of Instrument Feasibility } \\
\text { Requirements }\end{array}$ \\
\cline { 2 - 3 } & $\begin{array}{l}\text { Validity of Criteria } \\
\text { (Pearson } \\
\text { Correlation) }\end{array}$ & $\begin{array}{l}\text { The Difficulty } \\
\text { Level }\end{array}$ \\
\hline 1 & 0,393 & 0,647 \\
2 & 0,412 & 0,593 \\
3 & 0,100 (Invalid) & 0,56 \\
4 & 0,550 & 0,427 \\
5 & 0,592 & 0,34 \\
6 & $-0,338$ (Invalid) & 0,613 \\
7 & 0,613 & 0,453 \\
8 & 0,618 & 0,393 \\
9 & 0,62 & 0,487 \\
10 & 0,411 & 0,5 \\
Reliability (Cronbach's Alpha) & 0,365 (Reliabel) \\
N of Items $=$ & 10 & \\
\hline
\end{tabular}

Seen in both tables 5 and 6 above, that valid items generally have alpha Cronbach's values that are above $r$ table. This shows that the test instruments can be said to be reliable.

Based on the results of data analysis from a series of validation testing activities on learning devices and instruments for measuring critical thinking skills and scientific literacy, it can be concluded that the instrument of this study is valid. Both content validation that has been proven by expert validation and trial analysis in the form of reliability, the level of difficulty of the questions, and the distinguishing power indicate that the instrument of this study has met the requirements as a measure of accurate data collection used in research.

\section{Conclusion}

Based on the results of data analysis from a series of validation testing activities on learning devices and instruments for measuring critical thinking skills and scientific literacy, it can be concluded that the instrument of this study is valid. Both content validation that has been proven by expert validation and trial analysis in the form of reliability, the level of difficulty of the questions, and the distinguishing power indicate that the instrument of this study has met the requirements as a measure of accurate data collection used in research.

\section{References}

Anwar, H. 2015. Pengembangan Perangkat Pembelajaran IPA Model 5e dan Analisis Implikasinya terhadap Keterampilan Proses Sains dan Hasil Belajar Peserta Didik di SMP Negeri 2 Kopang. Tesis. Universitas Mataram.

Bilgin, I. 2009. The effects of guided inquiry instruction incorporating a cooperative learning approach on university students' achievement of acid and bases concepts and attitude toward guided inquiry instruction. Scientific Research and Essay 4(10): 10381046.

Ennis, R. H. 1985. A Logical basic for Measuring Critical Thinking skills. Educational Leadership, 43 (2): 44-48.

Firman, H. 2007. Laporan Analisis Literasi Sains Berdasarkan Hasil PISA Nasional. Jakarta: Puspendik.

Hanson, D. M. 2012. Designing Process-Oriented Guided-Inquiry Activities. Diakses dari http://quarknet.fnal.gov/fellows/TLDownlo ads/Designing_POGIL_Activities.pdf

Kemendikbud. 2013. Pedoman Penilaian Hasil Belajar. Jakarta: Kemendikbud.

Martondang, Z. 2009. Pengantar Evaluasi. Medan: PPS Unimed.

OECD. 2016. PISA 2015 Assessment and Analytical Framework: Science, Reading, Mathematic and Financial Literacy. Paris: OECD Publishing.

Puspendik. 2018. Capaian Nilai Ujian Nasional Provinsi NTB Tahun 2017/2018. Diakses dari puspendik.kemendikbud.go.id

Retnawati, H. 2016. Analisis Kuantitatif Instrumen Penelitian (Panduan Peneliti, Mahasiswa, dan Psikometrian). Yogyakarta: Parama Publishing.

Setiadi, D., 2013. Pengembangan Model pembelajaran Pembelajaran Untuk Meningkatkan Kemampuan Literasi Sains Peserta Didik SMP. Disertasi. Universitas Pendidikan Indonesia.

Sugiyono. 2018. Metode Penelitian Pendidikan Pendekatan Kuantitatif, Kualitatif, dan $R \& D$. Bandung: Alfabeta.

Susetyo, B. 2015. Prosedur Penyusunan \& Analisis Tes: Untuk Penilaian Hasil Belajar Bidang Kognitif. Bandung: Refika Aditama.

Udi, E. A., \& Cheng, D. 2015. Developing Critical Thinking Skills from Dispositions to Abilities: Mathematics Education from Early Childhood to High School. Creative Education, 6: 455-462. 
Wiersma, W. 1986. Research methods in education: an introduction. Massachussets: Allyn and Bacon, Inc.

Zohar, A., \& Dori, Y.J. 2003. Higher Order Thinking Skills and Low Achieving Students: Are They Mutually Exclusive? Journal of the Learning Sciences, 12: 145181. 